\title{
ACTUAL AND POTENTIAL HETEROTROPHIC NITROGEN FIXATION AND DENITRIFICATION RATES OF Oryza glumaepatula STEUD IN AN AMAZONIAN LAKE
}

\author{
ENRICH-PRAST, A., ${ }^{1}$ ESTEVES, F. A. ${ }^{1}$ and BIESBOER, D. D. ${ }^{2}$ \\ ${ }^{1}$ Laboratório de Limnologia, Departamento de Ecologia, Universidade Federal do Rio de Janeiro, \\ Cidade Universitária, Ilha do Fundão, C.P. 68020, CEP 21941-540, Rio de Janeiro, RJ, Brazil \\ ${ }^{2}$ Department of Plant Biology, 220 Biological Sciences Center, 1445 Gortner Avenue, \\ University of Minnesota, St. Paul, MN 55108, USA \\ Correspondence to: Alex Enrich-Prast, Laboratório de Limnologia, Departamento de Ecologia, Universidade \\ Federal do Rio de Janeiro, Cidade Universitária, Ilha do Fundão, C.P. 68020, CEP 21941-540, \\ Rio de Janeiro, RJ, Brazil, e-mail: aeprast@acd.ufrj.br \\ Received August 10, 1998 - Accepted September 26, 1998 - Distributed September 10, 1999
}

(With 1 figure)

\begin{abstract}
Estimates of the rates of heterotrophic nitrogen fixation (HNF) and denitrification by acetylene reduction and acetylene inhibition, respectively, were determined for the roots and culms of wild rice, Oryza glumaepatula, in Lake Batata, a lake severely impacted by the dumping of bauxite tailings into the lake basin. Two stations were established in different parts of the lake: one in a natural area and other in an impacted area of the lake. Plant assays were performed during the principle hydroperiods of dry (December) and flood (July) to determine both: a) Actual rates of HNF and denitrification, and b) potential rates of HNF after amending with glucose potential rates of denitrification after amending with glucose, glucose + nitrate, or nitrate alone. HNF was found to naturally exceed denitrification in this system. HNF and denitrification were consistently found to be greater for roots than culms but no correlation was found between rates of HNF or denitrification and water depth. It was determined that for HNF and denitrification that glucose and nitrate were the limiting factors in controlling those processes in roots and culms of $O$. glumaepatula. HNF and denitrification of $O$. glumaepatula does not appear to show differences between impacted and non-impacted areas.
\end{abstract}

Key words: biological nitrogen fixation, Amazonian lake, aquatic macrophyte.

\section{RESUMO}

\section{Taxas reais e potenciais de fixação heterotrófica de nitrogênio e de desnitrificação em Oryza glumaepatula Steud em um lago amazônico}

Foram estimadas taxas reais e potenciais de fixação heterotrófica de nitrogênio (FHN) e de desnitrificação pela metodologia da redução de acetileno e inibição por acetileno, respectivamente. Estas taxas foram determinadas para raízes e colmos de uma espécie selvagem de arroz, Oryza glumaepatula, presente no lago Batata, um ecossistema impactado pelo lançamento de rejeito de bauxita. Foram escolhidas duas estações de coleta no lago Batata: uma localizada na área natural e outra localizada na área impactada por rejeito de bauxita. Os experimentos foram realizados nos dois períodos mais representativos do pulso hidrológico: seca (dezembro) e cheia (julho). Foram determinadas: a) taxas reais de FHN e desnitrificação e b) taxas potenciais de FHN após a adição de glicose de taxas potenciais de desnitrificação após a adição de glicose, nitrato e nitrato + glicose. O processo de FHN excede o processo de desnitrificação nesse sistema. Os processos de FHN e de desnitrificação foram maiores em raízes do que em colmos de $O$. glumaepatula, porém nenhuma correlação foi encontrada entre estas taxas e a profundidade da água. Verificou-se que a glicose e o nitrato foram os fatores 
controladores dos processo de FHN e desnitrificação, respectivamente, em raízes e colmos de $O$. glumaepatula. Os processos de HNF e desnitrificação em perifíton associado a O. glumaepatula parecem não apresentar diferenças entre as áreas impactada e não-impactada.

Palavras-chave: fixação biológica de nitrogênio, lago Amazônico, macrófita aquática.

\section{INTRODUCTION}

Lake Batata is one of many clear water lakes lying in the floodplain of the Amazonian region. These floodplains are subject to widely fluctuating seasonal hydroperiods (Junk et al., 1989). However, Lake Batata differs from neighboring lakes of the region because for a decade (1979-1989) the northern end of the lake served as a dumping site for bauxite tailings from a local aluminum mine. Tailings, consisting principally of fine clay particles, were dumped into the lake at a rate of $5.0 \times 10^{4}$ $\mathrm{m}^{3} \mathrm{~d}^{-1}$. The total area of the lake impacted by tailings was $630 \mathrm{ha}$, or $30 \%$ of the total lake basin. In the impacted area of the basin, the tailings occur in suspension or cover the natural sediments. The non-impacted area of the lake remains in its natural state.

The lakeshore of both impacted and nonimpacted areas of Lake Batata is colonized by Oryza glumaepatula Steud (wild rice), one of 20 wild Oryza species that occurs in tropical and subtropical aquatic environments around the world (Morishima, 1994). The life cycle of this species and other aquatic macrophytes is regulated by annual oscillations in water level in the Amazon (Junk \& Piedade, 1993). Seeds of O. glumaepatula germinate in late October, November and early December as dry occurs and water levels decrease to expose shoreline sediments. Seedlings have a short terrestrial growth phase until filling begins and they become progressively inundated by rising water in mid- to late December. Stem elongation occurs rapidly and concomitantly with the steady rise in water level during the period of late December to late May. Plant elongation continues until the end of the flood period in June. As drawdown begins in July, stagnating water adjacent to the sediments becomes anoxic, and culms within approximately a meter of the sediment slowly begin to decompose and plants progressively disappear from the water column.

O. glumaepatula, as well as other macrophytes that grow in the same habitat, are important components of Amazonian aquatic ecosystems.
Some of these aquatic macrophyte species of the Amazon are among the most productive plant populations in the world (Junk \& Piedade, 1993); and because of their high primary production must be considered important contributors to biogeochemical cycles of the Amazon floodplain.

One of these biogeochemical cycles is the nitrogen cycle. Since nitrogen is a limiting nutrient to primary production in Amazonian ecosystems (Setaro \& Melack, 1984), large populations of aquatic macrophytes will influence nitrogen cycling in amazonian ecosystems. Yet, few studies of the relationships between nitrogen cycling and aquatic macrophytes of the Amazon have been published. Research has been limited to a handful of publications evaluating biological nitrogen fixation by periphyton associated with aquatic macrophytes in just a few Amazonian lakes (Melack \& Fisher, 1988; Doyle \& Fisher, 1994; Enrich-Prast \& Esteves, in press).

The aquatic macrophyte flora of Lake Batata is dominated by monospecific stands of $O$. glumaepatula.

Plants of this species are estimated to comprise about $90 \%$ of the biomass of aquatic macrophytes present in the water of the flooded shoreline in both impacted and non-impacted areas of the lake. In this paper, we examined actual and potential rates of heterotrophic nitrogen fixation (HNF) and actual and potential rates of denitrification associated with the seasonal development of $O$. glumaepatula in impacted and non-impacted areas of the lake. We tested how these two processes might be influenced by the availability of carbon (as glucose) and nitrate because their availability will control both HNF (Howard et al., 1988) and denitrification (Groffman, 1991; Brettar $\&$ Rheinheimer, 1992). In addition, we evaluate the anthropogenic impact caused by the bauxite tailings on both processes.

\section{METHODS}

Lake Batata can be classified as a clear-water lake (Sioli, 1984). It is located in the municipality 
of Oriximiná, State of Pará, on the floodplain of the Trombetas River (1³0'S and 56²0’W), a tributary of the left bank of the Amazon River. A detailed map of the lake and its location is found in Ferrão-Filho and Esteves (1994). As in most Amazonian floodplain lakes, the water level in Lake Batata varies annually. During the course of this research, the lake fluctuated ca. 8.0 meters in depth between the periods of filling (rising water levels); flood (highest water levels); drawdown (water levels decreasing), and dry (lowest water levels).

Data including the plant materials for assays were collected during the flood (June/1995) and dry (December/1995) periods which are the most representative periods of the floodpulse. Collections were made at two permanent stations located in typical large beds of wild rice on Lake Batata. One station was located in an area of the lake impacted by bauxite tailings; and the other station in a natural, or non-impacted, area of the lake.

In December, when shoreline sediments were exposed, entire seedlings (ca. $20 \mathrm{~cm}$ in height) and their root systems were collected from the sediments by careful excavation followed by minimal washing. During the flood period, when water depths approached their maximum of $8.0 \mathrm{~m}$, and wild rice culms began to separate from the root stocks. Plant materials consisting of $10 \mathrm{~cm}$ sections of culms and $10 \mathrm{~g}$ of adventitious roots were used for assays. During the flood periods, plant samples were taken at a depth of 0.5 and 3.0 meters from the water surface. Fig. 1 shows the development of O. glumaepatula, and its relationship to hydroperiod and sampling regime.

Adventitious roots present in sediments under 4 or more meters of water could not be collected because the culms were very friable and would break apart anywhere along their length from root stocks if attempts were made to pull mature plants from the water column.

Approximately $10 \mathrm{~g}$ of plant tissue were removed to pre-weighed $100 \mathrm{ml}$ glass bottles and temporarily capped. Bottles were kept cool and immediately transported to the laboratory. Five (5) replicates were performed for each of the six following treatements: 1 ) for estimations of the actual rate of heterotrophic nitrogen fixation (actual $\mathrm{HNF}$ ), flasks were amended with $10 \mathrm{ml}$ of distilled water; 2) for estimations of the potential rates of heterotrophic nitrogen fixation (potential HNF), the bottles were amended with $10 \mathrm{ml}$ of aqueous $2 \%(\mathrm{w} / \mathrm{v})$ glucose; 3 ) for estimations of the actual rate of denitrification, bottles were amended with $10 \mathrm{ml}$ of distilled water; 4) for estimations of potential denitrification with glucose, bottles were amended with $10 \mathrm{ml}$ of aqueous $2 \%$ (w/v) glucose; 5 ) for estimations of potential denitrification with nitrate, bottles were amended with $10 \mathrm{ml}$ of aqueous $0.6 \mathrm{mg} / \mathrm{KNO}_{3}$; and 6) for estimations of potential denitrification with glucose and nitrate, bottles were amended with the combination of $10 \mathrm{ml}$ of aqueous glucose $2 \%(\mathrm{w} / \mathrm{v})$ plus $0.6 \mathrm{mg} / \mathrm{KNO}_{3}$.

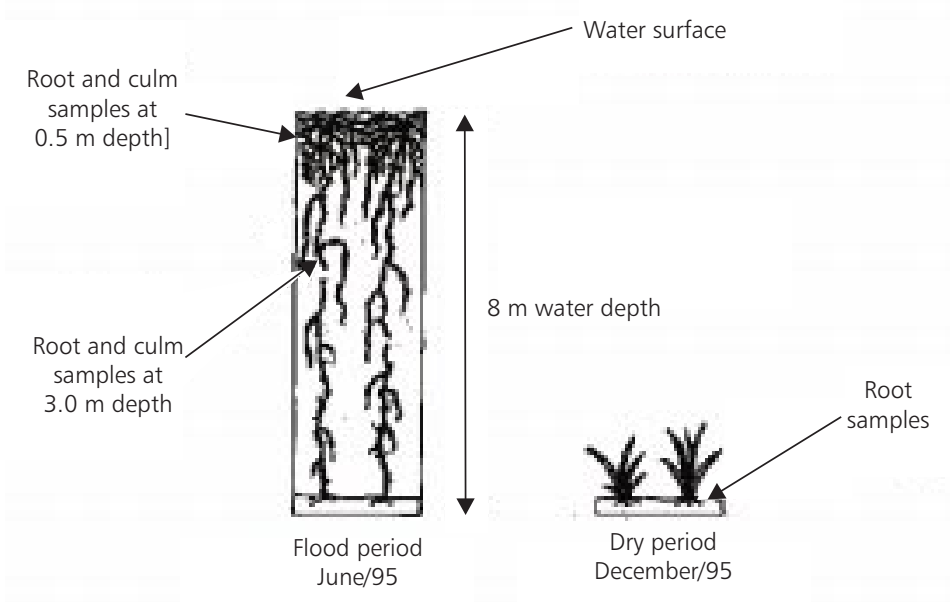

Fig. 1 - Development of O. glumaepatula in Lake Batata during the dry and flood periods in 1995. 
Immediately after the addition of amendments to the bottles, they were flushed with pure nitrogen (75 $\mathrm{ml} \mathrm{min}^{-1}$; $4 \mathrm{~min}$ ) to maintain anaerobic conditions. After flushing with nitrogen, the bottles were capped with serum stoppers. The time between plant collection and capping was always less than $1 \mathrm{hr}$.

Rates of actual HNF and potential HNF were determined by the acetylene reduction method (Hardy et al., 1973) and denitrification rates by the acetylene inhibition method (Yoshinari \& Knowles, 1976). At the beginning of each assay, $15 \%$ of the headspace of each bottle was removed with a syringe, replaced by an equal volume of acetylene, and subsequently gently agitated. Bottles were incubated in the dark at $26^{\circ} \mathrm{C}$. The 5 replicates were acompanied by 2 control samples not injected with acetylene to test for endogenous ethylene and nitrogen oxide production. The incubation time differed for each treatment. Incubations for actual HNF and actual DN were 4 hours. Incubations for assays containing amendments were performed for the period of 24 hours. At the end of the incubation period, $3.5 \mathrm{ml}$ of the headspace gas was removed with a syringe from each flask and transferred to $7.0 \mathrm{ml}$ Vacutainers.

Ethylene from the assays for actual and potential HNF was quantified in a Varian 3400 Chromatograph (FID detector at $200^{\circ}$; Porapak N column; oven temperature of $60^{\circ} \mathrm{C}$; injector temperature of $80^{\circ} \mathrm{C}$; nitrogen as the carrier gas at $40 \mathrm{ml} / \mathrm{min}$ ). A factor of 3 was used to convert nanomoles of ethylene produced to nanomoles of nitrogen fixed (Hardy et al., 1973). Nitrous oxide from the assays of actual and potential DN was quantified in a similar manner (ECD detector at $300^{\circ} \mathrm{C}$; Porapak $\mathrm{Q}$ column; oven temperature of $55^{\circ} \mathrm{C}$; injector temperature of $130^{\circ} \mathrm{C}$; nitrogen as the carrier gas at $40 \mathrm{ml} / \mathrm{min}$ ).

Water temperature and oxygen concentrations were measured in the field using a TAO Model DO-11P oxymeter. Concentrations of nitrate and ammonia in water and sediments were determined according to Golterman et al. (1978). Biomass of culms and adventitious roots were also determined at each station for each sampling period.

\section{RESULTS}

Individuals of Oryza glumaepatula grow very rapidly after germination and early establishment. Seeds of this graminaceous species germinate on the exposed floodplain and produce a large mass of adventitious roots from the base of the stem that penetrate approximately a half meter into the sediments. As water begins to reflood exposed sediments, elongation of culms occurs rapidly and in parallel with daily increases in water depth. Plants during the course of this study were observed to elongate between 3 to $6 \mathrm{cmd}^{-1}$. Large numbers of branched, fibrous adventitious roots developed at young nodes in both non-impacted and impacted areas of the lake and extend into the water column along the length of the stem. Water levels varied from zero to $8.0 \mathrm{~m}$ during the course of the growing season.

Table 1 illustrates mean values for actual HNF rates and potential HNF rates associated with adventitious roots and culms of $O$. glumaepatula at 0.5 and $3.0 \mathrm{~m}$ water depths in non-impacted and impacted areas of Lake Batata. Several trends can be noted about HNF associated with roots and culms at different water depths and between actual and potential rates of HNF. At all water depths, both actual and potential HNF associated with adventitious roots is significantly greater $(\mathrm{p}<0.05$; Mann-Whitney) than for culms, often being one order of magnitude greater. The lowest rates of actual HNF are associated with adventitious roots arising at the base of stem and penetrating the sediments in non-impacted and impacted areas during the dry period. Actual and potential HNF associated with adventitious roots arising from the stems and developing into the water column during filling and flood at depths of 0.5 and $3.0 \mathrm{~m}$ were always significantly greater $(\mathrm{p}<0.05$; MannWhitney) than roots developing in the sediments. Finally, actual and potential HNF were always significantly different ( $\mathrm{p}<0.05$; Mann-Whitney) between non-impacted and impacted areas at specific water depths. In some instances the difference between actual and potential HNF after glucose addition was dramatic, e.g., during the dry period in the non-impacted area the actual vs. potential were respectively 1.24 vs. $4356.9 \mu \mathrm{mol} \mathrm{N}$ fixed $\mathrm{kg}^{-1}$ D.W.d $\mathrm{d}^{-1}$ (Table 1). No discernible pattern can be observed for actual and potential HNF rates between different depths during the period of flood. Ethylene was not detectable in control bottles.

Table 2 illustrates mean values for potential denitrification with nitrate and nitrate + glucose associated with various organs of $O$. glumaepatula in non-impacted and impacted areas of Lake Ba- 
tata. Nitrous oxides were not detectable in bottles without addition of any substrate indicating that denitrification was not occurring in situ. Nitrous oxide also could not be detected in bottles that only received an amendment of glucose. Amendments with both nitrate and nitrate + glucose caused a significant evolution of nitrous oxide in our assays.

During the flood period, potential denitrification with amended nitrate in assays with adventitious roots was significantly greater than for culms, but potential denitrification with nitrate + glucose associated with adventitious roots was statistically similar ( $p<0.05$; Mann-Whitney) between the culms in the non impacted area at 3.0 $\mathrm{m}$ and in the impacted area at $0.5 \mathrm{~m}$.

At other depths, adventitious roots exhibited significantly greater rates of nitrous oxide evolution than culms. Significant differences between amendments was also obvious. Nitrate+glucose always significantly increased ( $p<0.05$; MannWhitney) nitrous oxide production in comparison to nitrate alone in both non-impacted and impacted areas at specific water depths during the flood period.
However, in seedlings growing terrestrially during the dry period, the opposite was observed. The nitrate amendment caused a significant increase in nitrous oxide evolution in comparison to nitrate + glucose.

No clear pattern was observed between potential denitrification rates in the non-impacted and impacted areas. In some cases, potential denitrification was significantly higher in impacted areas vs. the non-impacted areas or vice versa. In other cases, they were statistically similar.

Correlations between oxygen, nitrate or ammonium concentrations or temperature and actual or potential rates of nitrogen fixation or denitrification could be not found. Oxygen concentrations varied between 0.54 and $4.06 \mathrm{mg} / \mathrm{l}$ in the water column at different depths with lower levels of oxygen being found as expected at $3.0 \mathrm{~m}$ during the flood period. Nitrate and ammonium concentrations in the water column, sediments, or sediment pore water were very low. Nitrate was less than $18 \mu \mathrm{g} / \mathrm{l}$ and ammonium was less than $260 \mu \mathrm{g} / 1$. Water and sediment temperature varied from $27^{\circ} \mathrm{C}$ during flood to $31^{\circ} \mathrm{C}$ during the dry period.

TABLE 1

Mean values ( $\mu \mathrm{mol} \mathrm{N}$ fixed $\mathrm{kg}^{-1} \mathrm{D} . \mathrm{W} . \mathrm{d}^{-1} \pm$ S.D.) for actual nitrogen fixation rates and potential nitrogen fixation rates (glucose amendment) associated with various organs of Oryza glumaepatula at 0.5 and 3.0 meter water depths in non-impacted and impacted areas of Lake Batata.

\begin{tabular}{|c|c|c|c|c|}
\hline \multirow{2}{*}{ Hydroperiod } & \multicolumn{4}{|c|}{ Plant Organ, Water Depth (m) } \\
\hline & Roots, $0.5 \mathrm{~m}$ & Culms, $0.5 \mathrm{~m}$ & Roots, $3.0 \mathrm{~m}$ & Culms, $3.0 \mathrm{~m}$ \\
\hline \multicolumn{5}{|l|}{ Flood (June/95) } \\
\hline \multicolumn{5}{|l|}{ Non-impacted } \\
\hline - actual & $47.8 \pm 19.7$ & $14.5 \pm 2.3$ & $45.1 \pm 8.9$ & $7.8 \pm 0.8$ \\
\hline - potential & $293.8 \pm 26.9$ & $20.98 \pm 4.4$ & $647.5 \pm 230.4$ & $34.0 \pm 10.0$ \\
\hline \multicolumn{5}{|l|}{ Impacted } \\
\hline - actual & $130.5 \pm 68.8$ & $2.6 \pm 0.7$ & $15.0 \pm 12.2$ & $2.0 \pm 0.7$ \\
\hline - potential & $408.2 \pm 68.8$ & $8.5 \pm 1.0$ & $1445.5 \pm 1031.9$ & $8.0 \pm 3.5$ \\
\hline \multicolumn{5}{|c|}{ Dry (December/95) } \\
\hline \multicolumn{5}{|l|}{ Non-impacted } \\
\hline - actual & $1.2 \pm 0.6$ & & & \\
\hline - potential & $4356.9 \pm 1169.9$ & & & \\
\hline \multicolumn{5}{|l|}{ Impacted } \\
\hline - actual & $1.2 \pm 0.6$ & & & \\
\hline - potential & $129.6 \pm 31.6$ & & & \\
\hline
\end{tabular}

* Assays of adventitious roots present on terrestrial seedlings of O. glumaepatula during the dry season when standing water was not present in the littoral zone of Lake Batata. 
TABLE 2

Mean values ( $\mu \mathrm{mol} \mathrm{N}_{2} \mathrm{O} \mathrm{kg}$ D.W. $\mathrm{d}^{-1} \pm$ S.D.) for potential denitrification associated with various organs of Oryza glumaepatula at 0.5 and 3.0 meter depths in non-impacted and impacted areas of Lake Batata. Amendments included the addition of $\mathrm{NO}_{3}$ and $\mathrm{NO}_{3}+$ glucose.

\begin{tabular}{|c|c|c|c|c|}
\hline \multirow{2}{*}{ Hydroperiod } & \multicolumn{4}{|c|}{ Plant Organ, Water Depth (m) } \\
\hline & Roots, $0.5 \mathrm{~m}$ & Culms, $0.5 \mathrm{~m}$ & Roots, $3.0 \mathrm{~m}$ & Culms, $3.0 \mathrm{~m}$ \\
\hline \multicolumn{5}{|l|}{ Flood (June/95) } \\
\hline \multicolumn{5}{|l|}{ Non-impacted } \\
\hline$\cdot \mathrm{NO}_{3}$ & $149.0 \pm 108.5$ & $18.5 \pm 6.5$ & $55.1 \pm 12.8$ & $17.0 \pm 19.5$ \\
\hline$\cdot \mathrm{NO}_{3}+$ glucose & $1040.5 \pm 40.7$ & $179.9 \pm 46.4$ & $130.4 \pm 60.2$ & $99.9 \pm 23.0$ \\
\hline \multicolumn{5}{|l|}{ Impacted } \\
\hline$\bullet \mathrm{NQ}$ & $25.4 \pm 5.8$ & $11.0 \pm 3.2$ & $70.0 \pm 50.0$ & $1.2 \pm 1.3$ \\
\hline - NQ + glucose & $79.4 \pm 79.4$ & $158.4 \pm 70.5$ & $342.7 \pm 199.0$ & $51.5 \pm 10.0$ \\
\hline \multicolumn{5}{|l|}{ Dry (December/95) ${ }^{*}$} \\
\hline \multicolumn{5}{|l|}{ Non-impacted } \\
\hline • NQ & $72.0 \pm 9.9$ & & & \\
\hline - NQ + glucose & $4.6 \pm 2.7$ & & & \\
\hline \multicolumn{5}{|l|}{ Impacted } \\
\hline • NQ & $99.4 \pm 12.4$ & & & \\
\hline$\cdot \mathrm{NQ}+$ glucose & $14.9 \pm 16.8$ & & & \\
\hline
\end{tabular}

\section{DISCUSSION}

\section{Heterotrophic Nitrogen fixation}

HNF follows patterns that might be expected for aquatic macrophytes when nitrogen fixation is calculated as nitrogen fixed per day on a dry weight basis (Table 1).

Actual rates of HNF are always lower than potential rates of HNF that occur if roots or culms are amended with glucose. Actual rates represent the rate of fixation by heterotrophs when carbon is limited to exudation by plant organs or from other sources such as carbon from periphyton on plant surfaces or the water column. Augmentation of roots or culms with glucose illustrates the extent of carbon limitation placed on nitrogen fixation by organic carbon. Potential HNF rates can be from twice to several thousand times greater if a readily available source of carbon is supplied to diazotrophs inhabiting the rhizosphere or colonizing other plant surfaces. In this study, roots always have greater rates of nitrogen fixation associated with them when compared to culms. Roots will always provide greater surface areas and increased numbers of sites for colonization by nitrogen fixing bacteria (Dahman, 1968). The adventitious roots of $O$. glumaepatula form dense tangled masses at each node of the plant and certainly greatly exceed culms in total surface area on a dry weight basis.

HNF does not appear to show distinct differences for water depth or in impacted vs. nonimpacted areas. For both depth and impacted vs. non-impacted areas, HNF my be significantly lower, higher or similar without a discernible pattern. It has been shown that the sediments of the impacted areas have lower concentrations of carbon, nitrogen, and phosphorus suggesting that in impacted areas that both potential rates of HNF associated with roots in sediments will be limited by the general availability of plant nutrients (Esteves et al., 1990; Roland \& Esteves, 1993).

\section{Denitrification}

Nitrous oxide could not be detected when plant organs were directly assayed (actual denitrification rates) or when amended only with glucose. Nitrous oxide could only be detected in our numerous assays after the addition of nitrate to the assay vessels indicating that nitrate is the limiting factor for denitrification associated with O. glumaepatula (Table 2). 
The observed low concentrations of nitrate in the water column of $18 \mu \mathrm{gl}^{-1}$ can explain the lack of denitrification associated with wild rice because nitrate must be present in the water column or sediments for dentrification to occur. An absence of nitrate or low availability in the environment will limit denitrification in aquatic systems (Knowles, 1982; Groffman, 1991). Similar data were obtained for denitrification in the sediments of the same lake (Esteves et al., in preparation). In another study, Enrich-Prast \& Esteves (in press) evaluated the diurnal variation of the nitrogen fixation and denitrification rates in adventitious roots and culms of O. glumaepatula. These authors also could not detect natural rates of denitrification associated with $O$. glumaepatula during this study which they attributed to low concentrations of available nitrogen present in the water column. Additional proof of nitrate-limited denitrification in biofilms comes from Law et. al (1993) and Erickson \& Weisner (1996) whom could only measure the production of $\mathrm{N}_{2} \mathrm{O}$ in biofilms with addition of nitrate to their assays.

In the flood period during July, it was observed after nitrate is added as amendment to the assays that denitrification increases significantly ( $\mathrm{p}<0.05$; Mann-Whitney). In all cases, the addition of nitrate and glucose to the assays also increased denitrification, and always at greater rates than with nitrate alone. As for HNF, adventitious roots at both depths of 0.5 and $3.0 \mathrm{~m}$ show increased rates of denitrification when compared to culms. Again, this is probably due the greater colonizable surface area for microorganisms present within the rhizosphere. During the flood period, no particular pattern of denitrification could be discerned for plant organ or water depth.

Acknowledgements - We thank Dr. Fabio Roland and Dr. Reinaldo Bozelli for kind field assistance, and Cláudio Cardoso Marinho for assistance with laboratory analyses. We thank the company Mineração Rio do Norte for financial support, and $\mathrm{CNPq}$ (Brazil) for the scholarship of MsC. Alex Enrich-Prast.

\section{REFERENCES}

BRETTAR, I. \& RHEINHEIMER, G., 1992, Influence of carbon availability on denitrification in the central Baltic Sea. Limnol. Oceanog., 37(6): 1146-1163.

DAHMAN, R. C., 1968, Root Production and Turnover of Carbon in the root-soil Matriz of a grassland ecosystem. In: Publishing House Nauke.
DOYLE, R. D. \& FISHER, T. R., 1994, Nitrogen fixation by periphyton and plankton on the Amazon floodplain at Lake Calado. Biogeochem., 26: 41-66.

ENRICH-PRAST, A. \& ESTEVES, F. A., in press, Diurnal variation of rates of denitrification and nitrogen fixation of periphyton associated with Oryza glumaepatula Steud in an Amazonian lake. Hydrobiologia.

ERICKSON, P. G. \& WEISNER, S. E. B., 1996, Functional differences in epiphitic microbial communities in nutrient-rich freshwater ecosystems: an assay of denitrifying capacity. Freshwater Biology, 36(3b): 723730 .

ESTEVES, F. A., BOZELLI, R. L. \& ROLLAND, F., 1990, Lago Batata - Um Laboratório de Limnologia Tropical. Ciência Hoje, 11: 26-33.

FERRÃO-FILHO, A. S. \& ESTEVES, F. A., 1994, Nutritive value and sedimentation rates of particulate matter in the course of two flood pulses in an Amazonian Varzea lake. Arch. Hydrobiol., 130: 325-337.

GOLTERMAN, H. L., CLYMO, R. S. \& OHNSTAD, M. A. M., 1978, Methods for physical and chemical analysis of freshwater. Blackwell Scientific Publ., 214p.

GROFMAN, P. M., 1991, Ecology of Nutrification and denitrification in soil evaluated at scales relevant to atmospheric chemistry. In: J. E. Rogers \& W. B. Whitman (eds.), Microbiol production and consuption of greenhouse gases: methane, nitrous oxide and halomethanes. American Society for Microbiology Washington, pp. 201-218.

HARDY, R. W. F., BURNS, R. C. \& HOLSTEN, R. D., 1973, Applications of the acetylene-ethylene assay for measurement of nitrogen fixation. Soil Biol. Biochem., 5: 47-81.

HOWARD, R. W., MARINO, R. \& COLE, J. J., 1988, Nitrogen fixation in freshwater, estuarine and marine ecosystems. 1. Rates and importance. Lim. Ocean., 33: 669-687.

JUNK, W. J. \& PIEDADE, M. T. F., 1993, Biomass and primary-production of herbacious plant communities in the Amazon floodplain. Hydrobiol., 263: 155-162.

JUNK, W. J., BAILEY, P. B. \& SPARKS, R. E., 1989, The flood pulse concept in river-flood plain systems. In: D. P. Dodge (ed.), Proc. Int. Large River Symp. Can. Publ. Fish. Aquat. Sci., 106: 110-127.

JUNK, W. J., 1984, Ecology of the várzea, floodplain of Amazonian white water rivers. In: H. Sioli (ed.), The Amazon: Limnology and Landscape Ecology of a Mighty Tropical River and its Basin, W. Junk Publ., Dordrecht, pp. 215-244.

KNOWLES, R., 1982, Denitrification. Microbiological Reviews, 46(1): 43-70.

LAW, C. S., REES, A. P. \& OWENS, N. J. P., 1993, Nitrons oxide production by estuarine epiphyton. Limnology and Oceanography, 38: 435-441.

MELACK, J. M. \& FISHER, T. R., 1988, Denitrification and nitrogen fixation in an amazonian floodplain lake. Verh. Int. Verein. Limnol., 23: 2232-2236. 
MORISHIMA, H., 1994, Background information about Oryza species in tropical america. In: H. Morishima \& P. S. Martins (eds.), Investigation of plant genetic resources in the amazon basin with the emphasis on the genus Oryza, pp. 4-5.

ROLAND, F. \& ESTEVES, F. A., 1993, Dynamics of phosphorus, carbon and nitrogen in an Amazonian lake impacted by bauxite tailings (Batata Lake, Pará, Brazil). Verh. Internat. Verein. Limnol., 25: 925-930.

SETARO F. V. \& MELACK, J. M., 1984, Responses of phytoplankton to experimental fertilization with nitrogen and phosphorus in an Amazon floodplain lake. Limnol. Oceanogr., 29: 972-984.
SIOLI, H., 1984, Introduction to the history of the discovery of the Amazon and of research of Amazonia waters and landscapes. In: H. Sioli (ed.), The Amazon: Limnology and Landscape Ecology of a Mighty Tropical River and its Basin, W. Junk Publ., Dordrecht, pp. 1-13.

YOSHINARI, T. \& KNOWLES, R., 1976, Acetylene inhibition of oxide reduction by denitrifying bacteria. Biochem. Biophys. Res. Comm., 69: 705-710. 